\title{
SHEAR CAPACITY PREDICTION FOR STIRRUP-CORRODED RC BEAMS STRENGTHENED WITH FRP
}

\author{
Ahmed K. EL-SAYED* \\ Centre of Excellence for Concrete Research and Testing, Department of Civil Engineering, King Saud University, \\ P.O. Box 800, Riyadh 11421, Kingdom of Saudi Arabia
}

Received 5 December 2017; accepted 16 March 2018

\begin{abstract}
Corrosion of steel reinforcement represents one of the main causes of deterioration and degradation of reinforced concrete (RC) structures. Shear reinforcements (stirrups) as an outer reinforcement in RC beams are more susceptible to corrosion problems and damage. This paper describes an analytical procedure for predicting the shear capacity of stirrupcorroded RC beams strengthened in shear using FRP laminates. The procedure shows how to incorporate the effects of the damages due to corrosion of stirrups into the design equations. An experimental investigation has been conducted to provide experimental data on the shear capacity of RC beams with corrosion-damaged stirrups strengthened using carbon fiber reinforced polymer (CFRP) sheets. The experimental study comprised three beams of $200 \mathrm{~mm}$ wide, $350 \mathrm{~mm}$ deep, and $2800 \mathrm{~mm}$ long. The steel stirrups in the beams were corroded using an accelerated corrosion technique. After CFRP strengthening, the beams were tested in four-point bending under a simply supported span of $2400 \mathrm{~mm}$. The shear capacity of the strengthened beams was predicted using the proposed procedure and compared with the experimental ones. Good correlations were found between the predicted and experimental shear strength of the beams.
\end{abstract}

Keywords: corrosion, concrete beams, shear capacity, FRP strengthening, stirrups, prediction.

\section{Introduction}

Corrosion of steel reinforcement reduces the cross-sectional area of the bars which in turn reduces their capacity in resisting applied forces. In fact, this is not the only problem associated with the deterioration of reinforced concrete (RC) structures due to corrosion. The corrosion products are considered one of the critical problems associated with corrosion of steel reinforcement. These products expand to reach a volume that can be six times that of the uncorroded steel it replaces as reported by Mehta and Monteiro (1993). This will create large tensile stresses within the concrete which may lead to cracking and spalling of the concrete cover. Eventually, these corrosion damages will cause reductions in the service life and ultimate capacity of the RC structure.

Steel stirrups, due to their location as an outer reinforcement, are more susceptible to corrosion problems and damage. In addition, the diameter of steel stirrups is generally small compared to that of longitudinal reinforcing bars so that relative loss of the cross-sectional area due to corrosion in the stirrups is expected to be much more significant than that in the longitudinal bars. Recent studies on the effects of corrosion of shear reinforcement revealed the detrimental effect of stirrup corrosion on the shear strength and behavior of RC beams (El-Sayed, Hussain, \& Shuraim, 2016; Wang, X. Zhang, J. Zhang, Ma, \& Liu, 2015; Khan, François, \& Castel, 2014; Xia, Jin, \& Li, 2011; Suffern, El-Sayed, \& Soudki, 2010; Higgins \& Farrow, 2006; Rodriguez, Ortega, \& Casal, 1997). The studies indicated that the losses in shear resistance of the beams were proportional to the damage level of stirrups due to corrosion.

At the time of cracking due to corrosion, the reduction in the steel cross-sectional area is insignificant (Andrade, Alonso, \& Molina, 1993). Nevertheless, if repairs are not taken at this early stage, the corrosion will continue, leading to concrete delamination and spalling rendering exposed steel reinforcement. This would accelerate the corrosion rate; further reduce the steel cross-sectional area to a level that might cause sudden rupture of the reinforcing steel. Externally bonded fiber-reinforced polymers (FRP) have emerged as a promising rehabilitation system to upgrade deficient RC components. FRPs are characterized

${ }^{*}$ Corresponding author. E-mail: ahelsayed@ksu.edu.sa 
by their light weight, high strength to weight ratio, ease and speed of site installation, and excellent fatigue and corrosion resistance (ACI Committee, 2007). These excellent characteristics make FRPs more attractive as a repair material compared to other conventional repairs. Previous research confirmed the ability of FRP system to upgrade corrosion-damaged reinforced concrete elements under pure flexural loading (El Maaddawy \& Soudki, 2005; Bonacci \& Maalej, 2000). The effectiveness of FRP system to increase the structural capacity of corroded reinforced concrete columns under concentric loading has been reported in previous studies (Debaiky, Green, \& Hope, 2002; Pantazopoulou, Bonacci, Sheikh, Thomas, \& Hearn, 2001). On the other hand, few studies have been directed to examine the feasibility of using FRP strengthening for upgrading RC elements with corrosion-damaged stirrups $(\mathrm{Li}$, Wu, \& Wang, 2016; Qin, Dirar, Yang, Chan, \& Elshafie, 2015; El Maaddawy \& Chekfeh, 2013; Kage, Abe, \& Lee, 1997). The outcomes of these studies were encouraging; however, none of these studies provided practical procedure for evaluating the shear strength of FRP strengthened beams with corroded stirrups. To design FRP strengthening system for such members, the residual shear strength of the corroded beams before strengthening has to be assessed first, then the contribution of FRP strengthening system will be added to get the overall shear strength of the beams. The analytical procedures presented by Li et al. (2016) and El Maaddawy and Chekfeh (2013) for evaluating the residual shear strength of the corroded beams assumed that the actual mass loss of the steel stirrups due to corrosion is known while in real life, the actual mass loss of the embedded steel bars cannot be evaluated without destructive testing (Xia et al., 2011).

The current study presents procedure for assessing the shear strength of RC beams with corroded stirrups upgraded using FRP materials. The procedure shows how to evaluate the residual shear strength of corroded RC beams which is considered essential for designing the FRP strengthening system. In this procedure, the residual shear strength is evaluated based on the measurement of the width of the corrosion-induced cracks which can be practically measured in real life without destructive testing. The study uses the ACI 440.2R (ACI Committee, 2017) method for evaluating the contribution of the FRP component to the shear strength of the beams. The paper also presents experimental data on the shear strength of CFRP strengthened RC beams with corroded stirrups. The experimental data is used for verifying the assessment procedure.

\section{Shear capacity for FRP strengthened RC beams}

ACI Committee 440 in its document, ACI 440.2R (ACI Committee, 2017), indicates that the nominal shear strength, $V_{n}$, of an FRP-strengthened concrete member can be superimposed into three components. The three components comprise the concrete contribution, $V_{c}$, to shear strength, the steel stirrups contribution, $V_{s}$, and the contribution of the FRP external shear reinforcement, $V_{f}$ as follows:

$$
V_{n}=V_{c}+V_{s}+\psi_{f} V_{f},
$$

where $\psi_{f}$ is a reduction factor introduced based on a reliability analysis using previous experimental data. ACI 440 Committee recommends a value of 0.85 for $\psi_{f}$ for threesided FRP U-wrap or two-opposite sides strengthening schemes, while a value of 0.95 is recommended for fullywrapped members.

The $V_{c}$ shear component in Eq. (1) can be calculated according to ACI 318 code (ACI Committee, 2014) as follows:

$$
V_{c}=0.17 \lambda \sqrt{f_{c}{ }^{\prime}} b_{w} d,
$$

where $f_{c}{ }^{\prime}$ is the specified concrete strength; $\lambda$ is a factor accounting for the concrete density ( $\lambda=1$ for normal weight concrete); $b_{w}$ and $d$ are the web width of the beam and the depth of the tension steel, respectively.

For the shear strength provided by vertical steel stirrups, the ACI 318 code (ACI Committee, 2014) specifies Eq. (3):

$$
V_{s}=\frac{A_{v} f_{y v} d}{s}
$$

where $A_{v}$ is the area of steel stirrups within spacing $s$; and $f_{y v}$ is the yield strength of the steel stirrups.

The contribution of vertical FRP system, $V_{f}$, to shear strength of a member can be calculated according to ACI 440.2R (ACI Committee, 2017) as follows:

$$
V_{f}=\frac{A_{f v} \varepsilon_{f e} E_{f} d_{f v}}{s_{f}},
$$

where $A_{f v}$ and $E_{f}$ are the cross-sectional area and modulus of elasticity of FRP, $\varepsilon_{f e}$ is the effective FRP strain used for design, $d_{f v}$ is the effective depth of FRP shear reinforcement, and $s_{f}$ is the spacing of FRP shear reinforcement. The cross-sectional area of FRP reinforcement is calculated as given in Eq. (5) according to ACI 440.2R (ACI Committee, 2017):

$$
A_{f v}=2 n_{f} t_{f} w_{f},
$$

where $n_{f}$ is the number of FRP layers, $t_{f}$ is the thickness of one layer of FRP, and $w_{f}$ is the width of FRP strip.

The effective FRP strain $\varepsilon_{f e}$ in U-wraps is recommended by ACI $440.2 \mathrm{R}$ (ACI Committee, 2017) to be calculated using a bond-reduction coefficient $\kappa_{v}$ applicable to shear as given by:

$$
\varepsilon_{f e}=\kappa_{v} \varepsilon_{f u} \leq 0.004
$$

where $\varepsilon_{f u}$ is the ultimate strain of FRP. The coefficient $\kappa_{v}$ is calculated as follows (ACI 440.2R (2017)):

$$
\kappa_{v}=\frac{k_{1} k_{2} L_{e}}{11900 \varepsilon_{f u}} \leq 0.75,
$$

where $L_{e}$ is the active bond length, $k_{1}$ and $k_{2}$ are modifi- 
cation factors that account for the concrete strength and the type of wrapping scheme used, respectively. The active bond length can be calculated as follows (ACI 440.2R (2017)):

$$
L_{e}=\frac{23300}{\left(n_{f} t_{f} E_{f}\right)^{0.58}} .
$$

The modification factors $k_{1}$ and $k_{2}$ are calculated as given in Eq. (9) and Eq. (10), respectively (ACI 440.2R (2017)):

$$
\begin{aligned}
& k_{1}=\left(\frac{f_{c}{ }^{\prime}}{27}\right)^{2 / 3} ; \\
& k_{2}=\frac{d_{f v}-L_{e}}{d_{f v}} .
\end{aligned}
$$

ACI 440.2R (ACI Committee, 2017) limits the shear strength provided by reinforcement $\left(V_{s}+V_{f}\right)$ based on the following:

$$
V_{s}+V_{f} \leq 0.66 \sqrt{f_{c}{ }^{\prime}} b_{w} d .
$$

\section{Shear capacity for FRP strengthened RC beams with corroded stirrups}

El-Sayed et al. (2016) indicated that both $V_{c}$ and $V_{s}$ shear components are affected by the corrosion of steel stirrups. They indicated that $V_{c}$ may be influenced by the corrosion cracks that may lead to delamination and spalling of the concrete cover reducing the effective web width of the beam. On the other hand, El-Sayed et al. (2016) indicated that $V_{s}$ may be influenced by the sectional loss of the reinforcing steel bars of stirrups. Therefore, they proposed modifications to Eq. (2) and Eq. (3) for evaluating the residual shear capacities $V_{c, \text { corr }}$ and $V_{s, \text { corr }}$ provided by concrete and steel stirrups, respectively, for RC beams with corroded stirrups.

Eq. (2) is modified to calculate $V_{c, \text { corr }}$ as follows:

$$
V_{c, \text { corr }}=0.17 \lambda \sqrt{f_{c}^{\prime}} b_{w, \text { eff }} d \text {, }
$$

where $b_{\text {weff }}$ is the effective concrete beam width resisting shear which is given by:

$$
\begin{aligned}
& b_{\text {eff }}=b-2\left(c+d_{b}\right)+\frac{s}{5.5} \text { if } s \leq 5.5 c ; \\
& b_{w, e f f}=b_{w}-\frac{5.5}{s}\left(c+d_{b}\right)^{2} \text { if } s>5.5 c,
\end{aligned}
$$

where $c$ is the side concrete cover, $s$ is the stirrups spacing and $d_{b}$ is the stirrup bar diameter.

Eq. (3) is modified to calculate $V_{s, \text { corr }}$ as follows:

$$
V_{s, \text { corr }}=\frac{A_{v, e f f} f_{y v} d}{s} \text {, }
$$

where $A_{v, \text { eff }}$ is the effective stirrups area which can be determined as given by:

$$
A_{v, \text { eff }}=A_{s}-\Delta A_{s} \text {, }
$$

where $A_{s}$ is the uncorroded steel cross section and $\Delta A_{s}$ is reinforcing steel cross section loss due to corrosion. $\Delta A_{s}$ can be estimated based on the measured width of the corrosion-induced crack using Vidal, Castel, and François (2004) model as given in Eqs (16) and (17):

$$
\begin{aligned}
& \Delta A_{s, c r}=A_{s}\left[1-\left(1-0.001 \alpha \frac{7.53+9.32 c / d_{b}}{d_{b}}\right)^{2}\right] ; \\
& \Delta A_{s}=\frac{w}{0.0575}+\Delta A_{s, c r},
\end{aligned}
$$

where $\Delta A_{s, c r}$ is local steel cross-section loss necessary for crack initiation, $\alpha$ is pit concentration factor $(\alpha=2$ for homogenous corrosion; $4<\alpha<8$ for localized corrosion), and $w$ is corrosion crack width. Thus, by knowing the actual corrosion crack width, the sectional mass loss of the steel stirrups can be predicted as presented in Eq. (17) and then, the effective area of steel stirrups, $A_{v, \text { eff }}$ is determined as given by Eq. (15).

The nominal shear capacity of corroded strengthened RC beams, $V_{n, \text { corr }}$, can be calculated by modifying Eq. (1) as follows:

$$
V_{n, \text { corr }}=V_{c, \text { corr }}+V_{s, \text { corr }}+\psi_{f} V_{f} \text {. }
$$

Also Eq. (11) is modified to be:

$$
V_{s, \text { corr }}+V_{f} \leq 0.66 \sqrt{f_{c}^{\prime}} b_{w, \text { eff }} d \text {. }
$$

\section{Experimental investigation}

The experimental program consisted of tests on 3 fullscale RC beams as given in Table 1 . The test specimens were $200 \mathrm{~mm}$ wide, $350 \mathrm{~mm}$ deep, and $2800 \mathrm{~mm}$ long. The beams were reinforced with four $25 \mathrm{~mm}$-diameter deformed steel bars as main tensile reinforcement and two $10 \mathrm{~mm}$-diameter deformed steel bars as top reinforcement. The main tensile bars were anchored at the beam ends using standard hooks to prevent anchorage failure. The steel stirrups were deformed bars having a diameter of $8 \mathrm{~mm}$. The side concrete cover of the stirrups was $25 \mathrm{~mm}$. One of the shear spans of the beams was allowed to include corroded stirrups while the other shear span included uncorroded stirrups. The stirrup spacing in the test span was variable $(100,150$, and $200 \mathrm{~mm})$. The stirrups in the beams were corroded using an accelerated corrosion technique. The corroded beams were strengthened in shear using CFRP sheets. A section loss of $20 \%$ corrosion damage was targeted for this study. The designation of the beams uses the letter $B$ stands for beam. The first number, 20, refers to the target mass loss of $20 \%$. The second number $(100,150$, or 200$)$ stands for the stirrup spacing while the letter $\mathrm{S}$ stands for strengthened. The reinforcement details and dimensions of the beams are shown in Figure 1. The longitudinal steel bars were epoxy-coated to preclude corrosion of these elements. Additionally, electrical tape was used to cover and insulate the longitudinal bars at the intersections of the bars and the stirrups. After casting and curing the beams for 28 days, the accelerated 
corrosion process was started. The accelerated corrosion was conducted by impressing a constant current into the concrete beam specimens using an external direct current (DC) power supply. The stirrups in the test span were connected to the positive terminal of the power supply to act as an anode. The $U$ shape stainless steel tube was connected to the negative terminal of the power supply to act as a cathode. For the purpose of an accelerated corrosion, a current density of $0.4 \mathrm{~mA} / \mathrm{cm}^{2}$ was applied through the stirrups using the DC power supply. Faraday's Law was taken as guidance for determining the amount of time to produce the corrosion damage. The three beams of this study, B20-200S, B20-150S, and B20-100S, were designed to have the same dimensions, steel reinforcement, and target mass loss as beams B20-200, B20-150, and B20100 presented in a previous publication by the author (El-Sayed et al., 2016). Therefore, such beams can be used as control for the beams of this study to show the effect of CFRP strengthening on the shear strength of the corroded beams.

The yield strengths of the reinforcing steel bars were 495,530 , and $480 \mathrm{MPa}$ for 8,10 , and $25 \mathrm{~mm}$ diameter bars, respectively. The average concrete compressive strength based on standard cylinder tests is given in Table 2. The CFRP sheets used to repair the corroded beams were unidirectional woven carbon fiber fabrics having a commercial name of SikaWrap 230C. They were used in conjunction with a two component-epoxy laminating resin, Sikadur 330, to provide a composite strengthening system. The design thickness of dry fibers was $0.131 \mathrm{~mm}$, the tensile strength of the fibers was $4300 \mathrm{MPa}$ and the tensile modulus of elasticity of the fibers was $238 \mathrm{GPa}$. The corresponding properties of CFRP cured laminates were $350 \mathrm{MPa}$ tensile strength and $28 \mathrm{GPa}$ modulus of elasticity based on $1.0 \mathrm{~mm}$ thickness per layer. All of these properties are as provided by the manufacturer.

After completion of the accelerated corrosion process, the corrosion crack patterns and widths were traced and recorded. Before CFRP strengthening, structural epoxy adhesive was used to fill and repair the corrosion-induced cracks. The CFRP strengthening scheme used consisted of two layers of U-wraps. The CFRP repair procedure has two main steps: surface preparation and CFRP application. The surface was prepared by using a grinder with an abrasive attachment to round the bottom corners of the beam along the test span to avoid stress concentration in the CFRP sheets. The epoxy resin was mixed according to the manufacturer's instructions. The first coat of the epoxy resin was applied to the concrete surface using a roller. The CFRP sheet was adhered to the surface with the fibers perpendicular to the longitudinal axis of the beam. A second coat of resin was impregnated into the fabric using a steel roller. Then a second layer of CFRP was adhered. Finally, a sealer coat of epoxy resin was applied to the outer CFRP layer. The repaired beams were left to cure for 7 days at room temperature before structural testing. The CFRP layers were U-shaped strips of $100 \mathrm{~mm}$ width and spaced at the same spacing of corroded stirrups to ensure having CFRP strip at the section of each corroded stirrup. Figure 2 shows schematic diagrams of CFRP repair of the beams, whereas Figure 3 illustrates repaired beams after CFRP strengthening.

After CFRP repair, the beams were tested up to failure. The beams were tested in four-point bending over a simply-supported clear span of $2400 \mathrm{~mm}$ and a shear span to depth ratio, a/d $=3$, as shown in Figure 1. In each beam, electrical resistance strain gauges were bonded to the longitudinal reinforcing steel and to the top concrete surface at midspan. No strain gauges were attached to the stirrups to be corroded as they would be destroyed during the accelerated corrosion phase. Electrical resistance strain gauges were bonded to the CFRP sheets at mid height. The deflection at midspan was measured using two LVDTs at each side of the beam. More information about the fabrication of the beams, accelerated corrosion, instrumentation, and test setup can be found in El-Sayed et al. (2016).
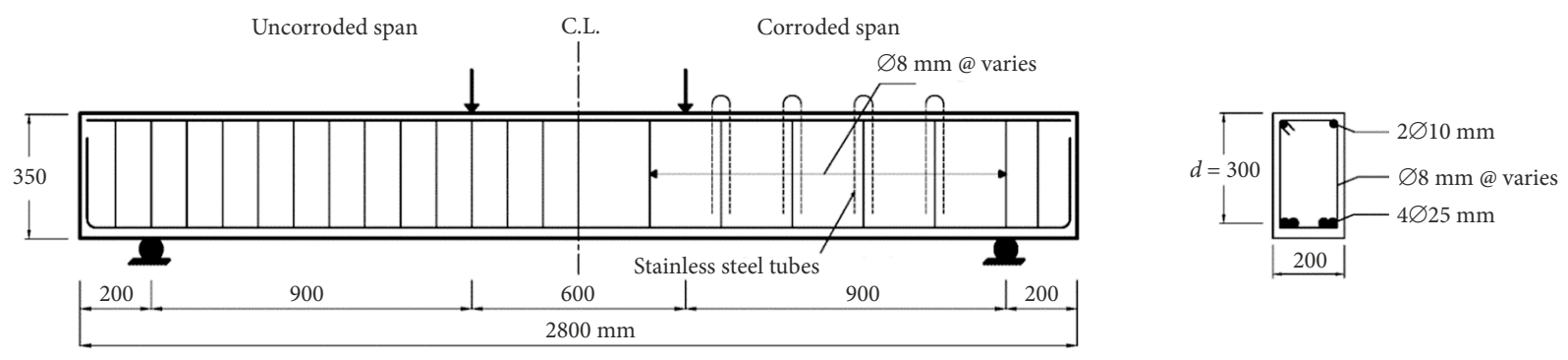

Figure 1. Reinforcement details and dimensions

Table 1. Test beams and corrosion damage measurements

\begin{tabular}{|c|c|c|c|c|}
\hline Beam & Stirrup spacing in the corroded span (mm) & Target mass loss (\%) & Measured mass loss (\%) & Measured crack width (mm) \\
\hline B20-200S & 200 & 20 & 16.7 & 0.32 \\
\hline B20-150S & 150 & 20 & 17.5 & 0.4 \\
\hline B20-100S & 100 & 20 & 17.4 & 0.38 \\
\hline
\end{tabular}




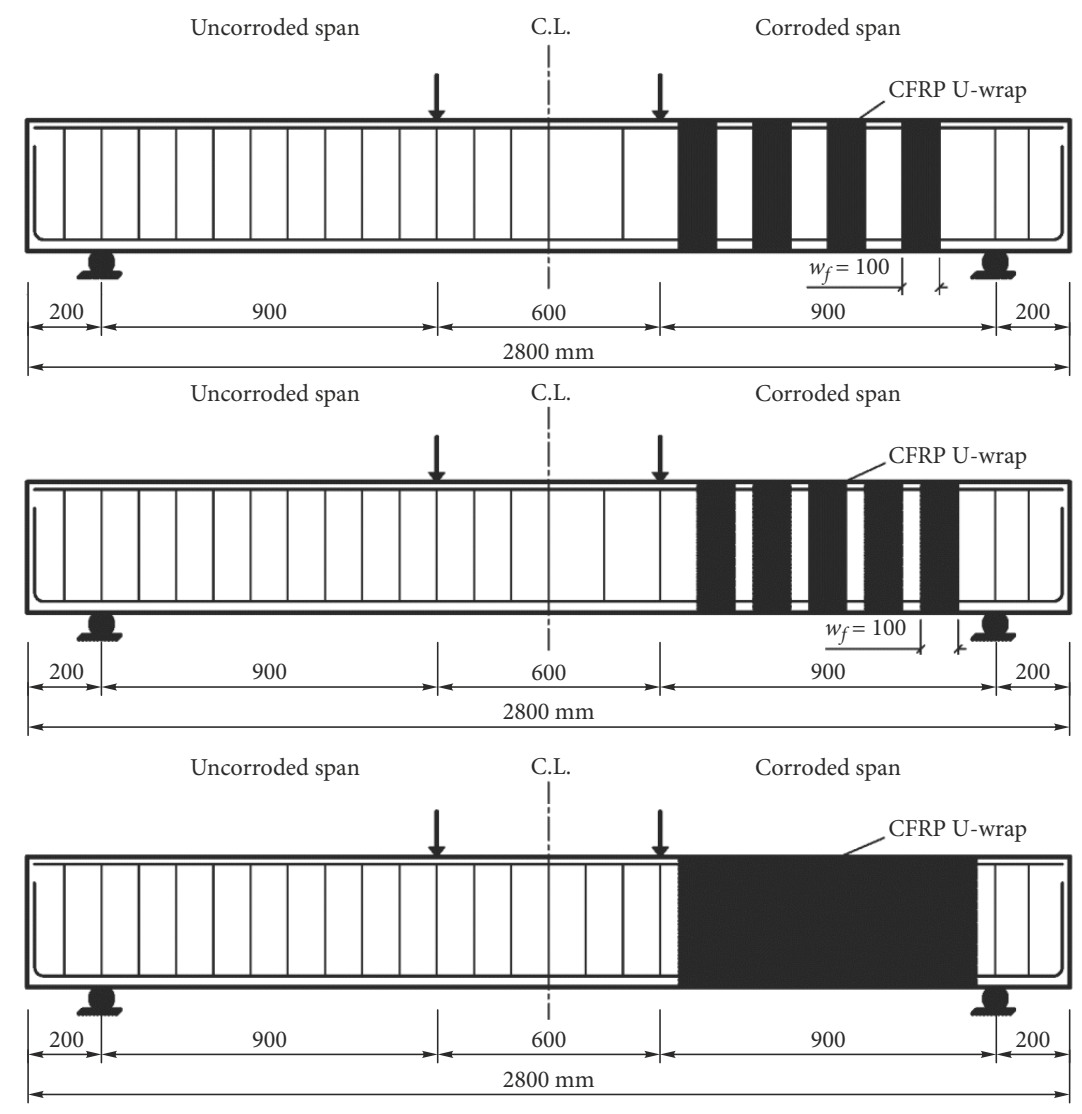

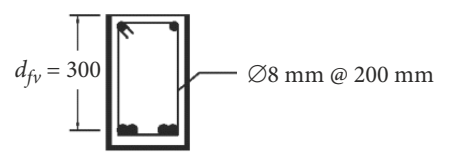

Beam 20-200S

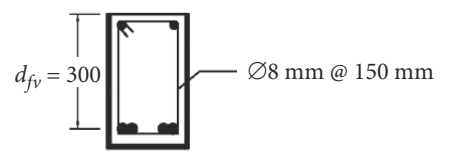

Beam 20-150S

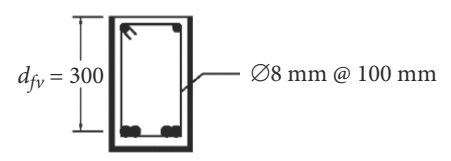

Beam 20-100S

Figure 2. Schematic of CFRP repair of the beams

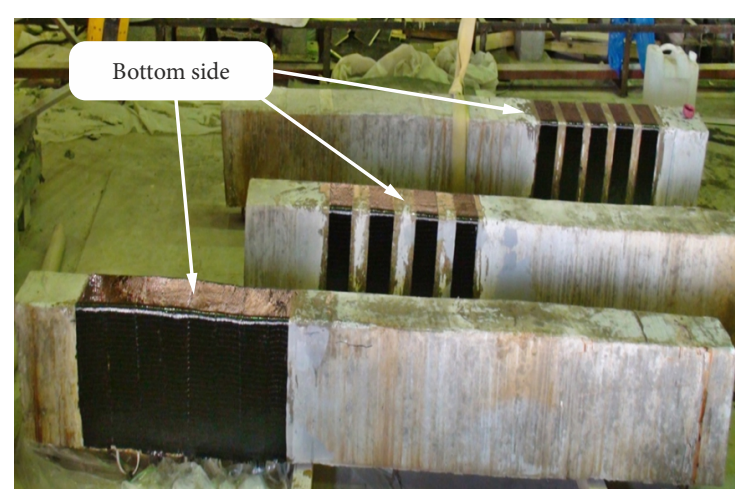

Figure 3. CFRP strengthened beams

\section{Experimental results and discussion}

The beams showed corrosion cracks and rust staining due to corrosion of stirrups. The cracks were primarily verti$\mathrm{cal}$ at the locations of the stirrups. The crack widths were measured manually using a microscope. The measurements were taken after the accelerated corrosion phase was completed and prior to structural testing. Table 1 summarizes the measured crack width for each beam. The table also gives the mass loss measured for each beam after structural testing. The actual mass loss of the corroded stirrups was determined based on the procedure specified in ASTM G1-03 (2011). After structural testing, corroded stirrups were removed from the beam to determine the amount of section mass loss. Reinforcing steel coupons that had a length of $200 \mathrm{~mm}$ were extracted from both legs of corroded stirrups for mass loss measurements. The mass loss for each beam was determined based on the average mass loss for the shear reinforcement in the failure region. It can be noted that beam B20-200S exhibited lower crack width and mass loss than those of beams B20-150S and B20-100S.

Table 2 gives a summary of the test results of the beams including the failure mode of the beams as in the last column of the table. Strengthened beam B20-200S failed by delamination of the concrete cover. This mode of failure occurred suddenly by separation of CFRP sheets with the concrete cover from the web of the beam after formation of diagonal crack. On the other hand, strengthened beams B20-150S and B20-100S failed in shear compression which is characterized by crushing of the concrete above the upper end of the inclined crack. Figure 4 illustrates by photograph the delamination of CFRP strips with the concrete cover of beam B20-200S.

The applied load versus midspan deflection plots for the tested beams are presented in Figure 5. The figure shows approximately linear relationship up to failure indicating the brittle nature of the shear failure. The three beams exhibited the same stiffness up to a load of $200 \mathrm{kN}$. Then, beam B20-200S started to exhibit lower stiffness followed by beam B20-150S and by beam B20-100S which showed the highest stiffness. This behavior may be at- 
tributed to the difference in the spacing of steel stirrups and FRP $U$ wraps in the beams. Figure 5 also shows that strengthened beam B20-200S exhibited a sudden drop in the load at the peak value unlike the two other strengthened beams B20-150S and B20-100S. This indicates the more brittle nature of the debonding failure mode of the CFRP sheets of beam B20-200S compared with the shear compression failure mode experienced by beams B20-150S and B20-100S.

Table 2 gives the measured midspan strains in the longitudinal reinforcement and concrete at failure for each beam. It should be noted that the strain gauges for beam B20-100S malfunctioned and no strain data for steel reinforcement and concrete were recorded for this beam. For beams B20-200S and B20-150S, the measured midspan concrete compressive strain was 2069 and 2255 micro-strain, respectively, which is lower than the concrete crushing strain. The tensile strain developed in the longitudinal bars at failure for the two beams was 2046 and 2238 micro-strain which is less than the yield strain of 2400 micro-strain of these bars. These results indicate that no flexural failure has occurred either by yielding of the longitudinal steel bars or by concrete crushing.

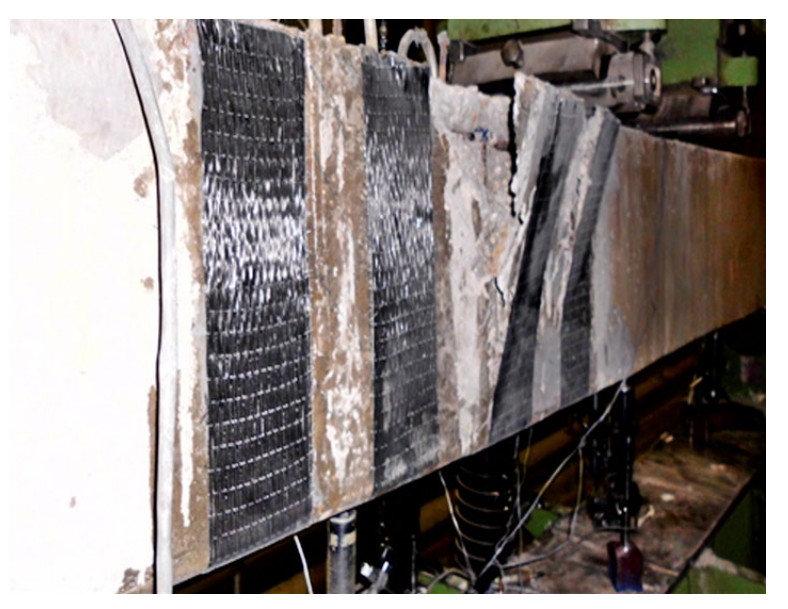

Figure 4. Delamination of concrete covert failure mode (B20-200S)
The applied load-strain plots for the CFRP sheets are shown in Figure 6. It can be seen from the figure that the CFRP sheets did not capture strain before diagonal cracking. After the formation of diagonal cracking at an average load of about $170 \mathrm{kN}$, CFRP sheets began to capture strain as they started to resist crack opening. At the beginning of this stage, beam B20-200S with wider spacing of CFRP

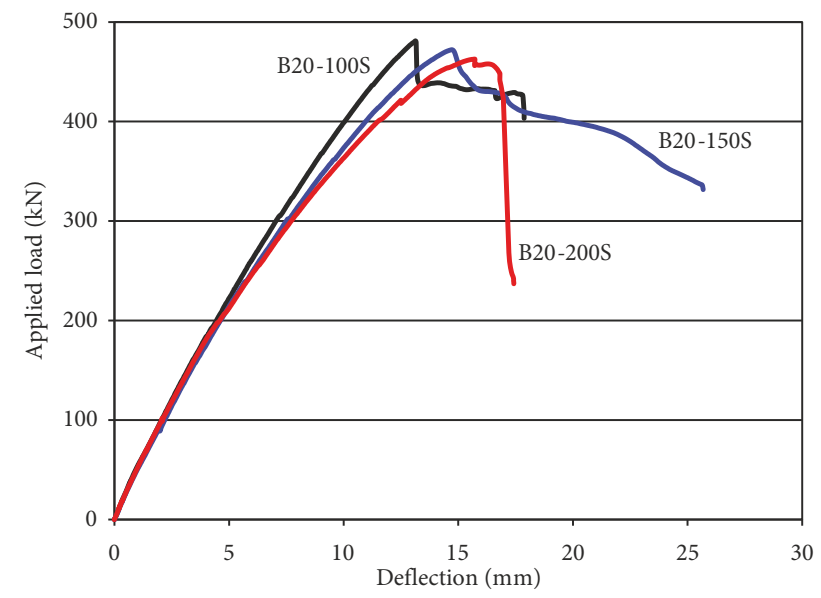

Figure 5. Load-deflection relationship for the test beams

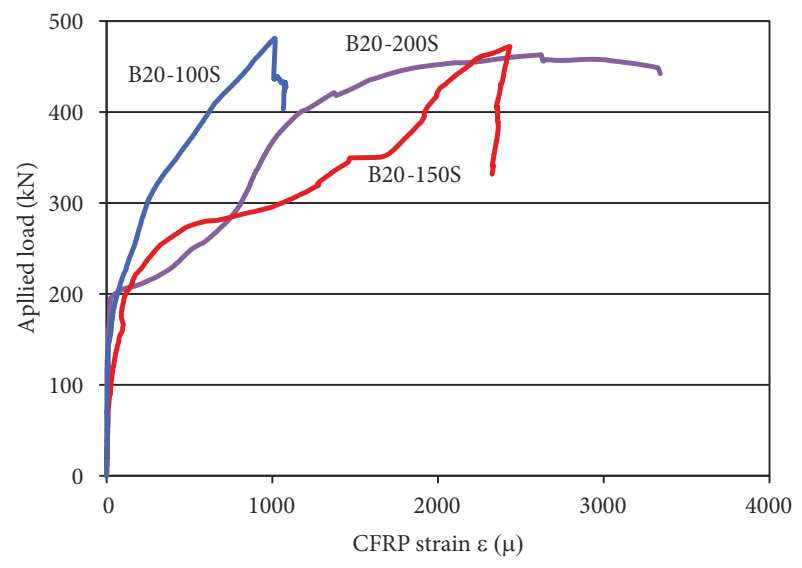

Figure 6. Load versus CFRP strain for strengthened beams

Table 2. Summary of test results

\begin{tabular}{|c|c|c|c|c|c|c|c|c|c|c|c|}
\hline \multirow{2}{*}{ Beam } & \multirow{2}{*}{$\begin{array}{c}f_{c}^{\prime} \\
(\mathrm{MPa})\end{array}$} & \multirow{2}{*}{$\begin{array}{l}\text { Ultimate } \\
\text { load } \\
(\mathrm{kN})\end{array}$} & \multirow{2}{*}{$\begin{array}{c}\text { Reinf. Ratio } \\
\text { of steel } \\
\text { stirrups, } \\
\rho_{v}(\%)\end{array}$} & \multirow{2}{*}{$\begin{array}{l}\text { Reinf. } \\
\text { Ratio } \\
\text { of FRP, } \\
\rho_{f v}(\%)\end{array}$} & \multirow{2}{*}{$\begin{array}{l}\text { Ultimate } \\
\text { shear } \\
\text { strength } \\
V_{u, \exp } \\
(\mathrm{kN})\end{array}$} & \multirow{2}{*}{$\begin{array}{c}\text { Normalized } \\
\text { shear stress } \\
\text { at failure } \\
\frac{V_{u, \exp }}{b d \sqrt{f_{c}^{\prime}}}\end{array}$} & \multirow{2}{*}{$\begin{array}{l}\text { Mid-span } \\
\text { deflection } \\
\text { at failure } \\
(\mathrm{mm})\end{array}$} & \multicolumn{2}{|c|}{$\begin{array}{c}\text { Mid-span strain } \\
(\mu \varepsilon)\end{array}$} & \multirow{2}{*}{$\begin{array}{c}\text { CFRP } \\
\text { strain } \\
(\mu \varepsilon)\end{array}$} & \multirow{2}{*}{$\begin{array}{l}\text { Failure } \\
\text { mode }^{*}\end{array}$} \\
\hline & & & & & & & & $\begin{array}{c}\text { Long. } \\
\text { bars }\end{array}$ & concrete & & \\
\hline B20-200S & 46.4 & 462 & 0.25 & 0.13 & 231 & 0.55 & 15.7 & 2046 & -2069 & 3341 & $\mathrm{DL}$ \\
\hline B20-150S & 40.6 & 472 & 0.34 & 0.17 & 236 & 0.60 & 14.7 & 2238 & -2255 & 2432 & SC \\
\hline B20-100S & 40.4 & 481 & 0.5 & 0.26 & 240.5 & 0.62 & 13.1 & -+ & -+ & 1015 & $\mathrm{SC}$ \\
\hline $\mathrm{B} 20-200^{\star *}$ & 40.7 & 272 & 0.25 & - & 136 & 0.35 & 9.4 & 1300 & 1027 & - & SR \\
\hline $\mathrm{B} 20-150^{* *}$ & 40.9 & 346 & 0.34 & - & 173 & 0.44 & 12.9 & 1808 & 1383 & - & SR \\
\hline $\mathrm{B} 20-100^{* *}$ & 44.0 & 345 & 0.5 & - & 172.5 & 0.42 & 13.5 & 18.7 & 1335 & - & SR \\
\hline
\end{tabular}

Note: ${ }^{\star} \mathrm{DL}=$ delamination of concrete cover, $\mathrm{SC}=$ shear compression, $\mathrm{SR}=$ stirrup rupture; ${ }^{*}$ unstrengthened corroded beams tested by El-Sayed et al. (2016); + Strain gauge malfunctioned. 
reinforcement showed highest rate of strain increase, followed by beam B20-150S, and then by beam B20-100S with continuous CFRP sheets. However, at a load level of $285 \mathrm{kN}$, the rate of CFRP strain increase for beam B20-200S reduced showing lower strain behavior than that of beam B20-150S. At a load level of $400 \mathrm{kN}$, the rate started to increase again and the beam experienced the highest CFRP strain at failure. As given in Table 2, the maximum strain developed in the CFRP sheets at failure was 3341 micro-strain for beam B20-200S, followed by 2432 micro-strain for beam B20-150S, and then by 1015 micro-strain for beam B20-100S. This result indicates that the strain increases with the increase of CFRP spacing. Also, the mode of failure affected the obtained strain values. Beam B20-200S experienced relatively higher value of CFRP strain compared to the other two beams because it failed by delamination of CFRP strips. On the other hand, the other two beams failed by shear compression before debonding of CFRP strips. The value of the debonding strain of CFRP strips of beam B20-200S represents about $19 \%$ of the ultimate strain of the CFRP materials.

The ultimate shear strength, $V_{u \text {,exp }}$, of the tested beams is given in Table 2. To eliminate the effect of the variation in concrete strength of the beams, the ultimate shear stress $\left[V_{u, \exp } /\left(b_{w} d\right)\right]$ for each beam was normalized with respect to the square root of its compressive strength $\left[V_{u, \exp } /\left(b_{w} d\right.\right.$ $\left.\left.\sqrt{f_{c}{ }^{\prime}}\right)\right]$ as presented in Table 2 . As can be seen from the table, the strengthened beams gave normalized shear stresses of $0.55,0.6$, and 0.62 respectively for beams B20-200S, B20-150S, and B20-100S. The corresponding values of the normalized shear stresses for the control beams of corroded stirrups without strengthening reported in El-Sayed et al. (2016) and given also in Table 2 were 0.35, 0.44, and 0.42 . These results indicate that the normalized shear stresses of the strengthened corroded beams increased by 57,36 , and $47 \%$ over their counterparts without strengthening. This clearly indicates the feasibility and effectiveness of using CFRP strengthening as a repairing system for RC beams with corroded stirrups.

\section{Comparison of predictions and experimental results}

The shear strengths of the corroded beams strengthened with CFRP sheets were calculated using Eq. (18) considering the upper limit of shear reinforcement contribution of Eq. (19), as given in Table 3. The shear strength components, $V_{c, \text { corr }}, V_{s, c o r r}$ and $V_{f}$ were calculated using Eqs (12),
(14), and (4), respectively and were presented in Table 3 for each strengthened beam. Both components of $V_{c, c o r r}$ and $V_{\text {s,corr }}$ were calculated considering the measured corrosion crack width. It should be pointed out that the reduction factor $\psi_{f}$ was set to equal one in the calculations. Also, it should be noted that the calculated CFRP shear component $V_{f}$ of beam B20-100S according to Eq. (4) was $138 \mathrm{kN}$, while the value of $V_{f}$ given in Table 3 is $69.8 \mathrm{kN}$. This is because $V_{f}$ of this beam of heavy shear reinforcement was governed by the limit of shear reinforcement contribution of Eq. (19). Table 3 also compares between the experimental shear capacities of the tested beams and the calculated capacities. The comparison shows that the analytical procedure followed in this paper provides accurate predictions for the shear capacities of the strengthened corroded beams as the average ratio of the experimental to calculated capacities was 1.07 with a coefficient of variation of $8 \%$.

More experimental data are required for further verifying the analytical procedure described in this paper. It is important for any future study on the topic to measure and report the width of the corrosion-induced cracks. This will allow use the described procedure for assessing the shear capacity of the beams. Unfortunately, none of the few studies available in the literature reported the width of the corrosion cracks.

\section{Conclusions}

This paper presented an analytical procedure for assessing the shear capacity of RC beams with corrosion-damaged stirrups strengthened using CFRP sheets. The analytical procedure considers the width of the corrosion-induced cracks as a measure of the sectional losses of the reinforcing steel bars. The paper also presented the test results of an experimental investigation on the shear strength of such beams. Based on this investigation, the following conclusions can be made:

- CFRP shear strengthening of RC beams with corroded stirrups was effective in enhancing the shear capacity of the beams.

- The beam that failed by delamination of the CFRP sheets experienced debonding strain of 3341 microstrain which represented $19 \%$ of the rupture strain of CFRP sheets.

- The analytical procedure provided accurate and consistent predictions for the shear capacity of the tested corroded beams with CFRP strengthening.

Table 3. Comparison of shear capacity between analytical and experimental results

\begin{tabular}{|c|c|c|c|c|c|c|}
\hline Beam & $V_{u, \exp }(\mathrm{kN})$ & $V_{c, \text { corr }}(\mathrm{kN})$ & $V_{s, \text { corr }}(\mathrm{kN})$ & $V_{f}(\mathrm{kN})$ & $V_{n, \text { corr }}(\mathrm{kN})$ & $V_{u, \exp } / V_{n, \text { corr }}$ \\
\hline $20-200 S$ & 231 & 59 & 62.2 & 75.7 & 196.9 & 1.17 \\
\hline $20-150 S$ & 236 & 52.3 & 80.3 & 92.3 & 224.9 & 1.05 \\
\hline $20-100 S$ & 240.5 & 49.3 & 121.4 & 69.8 & 240.5 & 1.0 \\
\hline & & & & & $\begin{array}{r}\text { Average } \\
\text { SD } \\
\text { COV (\%) }\end{array}$ & $\begin{array}{c}1.07 \\
0.09 \\
8\end{array}$ \\
\hline
\end{tabular}




\section{Acknowledgements}

The author would like to thank the engineers and technicians in the Center of Excellence for Concrete Research \& Testing (CoE-CRT) and in the structural laboratory of Civil Engineering Department at King Saud University for their help in preparing and testing the beams of this study.

\section{Funding}

This work was supported by the National Plan for Science, Technology and Innovation (MAARIFAH), King Abdulaziz City for Science and Technology, Kingdom of Saudi Arabia [award number 10-BUI1191-02].

\section{References}

ACI Committee. (2014). Building code requirements for structural concrete and commentary (ACI 318-14/ACI 318R-14). American Concrete Institute, Farmington Hills, MI.

ACI Committee. (2017). Guide for the design and construction of externally bonded FRP systems for strengthening concrete structures (ACI 440.2R-17). American Concrete Institute, Farmington Hills, MI.

ACI Committee. (2007). Report on fibre-reinforced polymer (FRP) reinforcement for concrete structures (ACI 440-07). American Concrete Institute, Farmington Hills, MI.

Andrade, C., Alonso, C., \& Molina, F. J. (1993). Cover cracking as a function of bar corrosion: Part 1-experimental test. $\mathrm{Ma}$ terials and Structures Journal, 26, 453-464. https://doi.org/10.1007/BF02472805

ASTM G1-03. (2011). Standard practice for preparing, cleaning and evaluating corrosion test specimens. ASTM International, West Conshohocken, Pa.

Bonacci, F. J., \& Maalej, M. (2000). Externally bonded fibrereinforced polymer for rehabilitation of corrosion damaged concrete beams. ACI Structural Journal, 97(5), 703-711.

Debaiky, A. S., Green, M. F., \& Hope, B. B. (2002). Carbon fibrereinforced polymer wraps for corrosion control and rehabilitation of reinforced concrete columns. ACI Materials Journal, 99(2), 129-137.

El Maaddawy, T., \& Chekfeh, Y. (2013). Shear strengthening of T-beams with corroded stirrups using composites. ACI Structural Journal, 110(5), 779-789.

El Maaddawy, T., \& Soudki, K. A. (2005). Carbon fibre-reinforced polymer repair to extend service life of corroded reinforced concrete beams. ASCE Composites for Construction Journal, 9(2), 187-194. https://doi.org/10.1061/(ASCE)1090-0268(2005)9:2(187)

El-Sayed, A. K., Hussain, R. R., \& Shuraim, A. B. (2016). Influence of stirrup corrosion on shear strength of reinforced concrete slender beams. ACI Structural Journal, 113(6), 12231232. https://doi.org/10.14359/51689147

Higgins, C., \& Farrow, W. C. (2006). Tests of reinforced concrete beams with corrosion damaged stirrups. ACI Structural Journal, 103(1), 133-141.

Kage, T., Abe, M., \& Lee, H. (1997). Effect of CFRP sheets on shear strengthening of RC beams damaged by corrosion of stirrup. In The Third International Symposium on Non-Metallic (FRP) Reinforcement for Concrete Structures (pp. 443-450). Sapporo, Japan. Japan Concrete Institute.
Khan, I., François, R., \& Castel, A. (2014). Experimental and analytical study of corroded shear-critical reinforced concrete beams. Materials and Structures Journal, 47, 1467-1481. https://doi.org/10.1617/s11527-013-0129-y

Li, H., Wu, J., \& Wang, Z. (2016). Shear performance of reinforced concrete beams with corroded stirrups strengthened with carbon fibre-reinforced polymer. ACI Structural Journal, 113(1), 51-61. https://doi.org/10.14359/51687913

Mehta, P., \& Monteiro, J. (1993). Concrete, structure properties, and materials (2nd ed., pp. 160-164). Englewood Cliff: Prentice-Hall.

Pantazopoulou, S. J., Bonacci, J. F., Sheikh, S., Thomas, M., \& Hearn, N. (2001). Repair of corrosion-damaged columns with FRP wraps. ASCE Composites for Construction Journal, 5(1), 3-11. https://doi.org/10.1061/(ASCE)1090-0268(2001)5:1(3)

Qin, S., Dirar, S., Yang, J., Chan, A., \& Elshafie, M. (2015). CFRP shear strengthening of reinforced-concrete T-beams with corroded shear Links. ASCE Composites for Construction Journal, 19, 04014081. https://doi.org/10.1061/(ASCE)CC.1943-5614.0000548

Rodriguez, J., Ortega, L., \& Casal, J. (1997). Load carrying capacity of concrete structures with corroded reinforcement. Construction and Building Materials, 11, 239-248. https://doi.org/10.1016/S0950-0618(97)00043-3

Suffern, C., El-Sayed, A. K., \& Soudki, K. (2010). Shear strength of disturbed regions with corroded stirrups in reinforced concrete beams. Canadian Journal of Civil Engineering, 37(8), 1045-1056. https://doi.org/10.1139/L10-031

Vidal, T., Castel, A., \& François, R. (2004). Analyzing crack width to predict corrosion in reinforced concrete. Cement and Concrete Research, 34, 165-174. https://doi.org/10.1016/S0008-8846(03)00246-1

Wang, L., Zhang, X., Zhang, J., Ma, Y., \& Liu, Y. (2015). Effects of stirrup and inclined bar corrosion on shear behavior of RC beams. Construction and Building Materials, 98, 537-546. https://doi.org/10.1016/j.conbuildmat.2015.07.077

Xia, J., Jin, W., \& Li, L. (2011). Shear performance of reinforced concrete beams with corroded stirrups in chloride environment. Journal of Corrosion Science, 53, 1794-1805. https://doi.org/10.1016/j.corsci.2011.01.058 